\title{
Suitable extracellular oxidoreduction potential inhibit rex regulation and effect central carbon and energy metabolism in Saccharopolyspora spinosa
}

Xiangmei Zhang ${ }^{1,2,3}$, Chaoyou Xue ${ }^{1,2,3}$, Fanglong Zhao ${ }^{1,2,3}$, Dashuai Li ${ }^{1,2,3}$, Jing Yin ${ }^{1,2,3}$, Chuanbo Zhang ${ }^{1,2,3}$, Qinggele Caiyin ${ }^{1,2,3}$ and Wenyu Lu, $\mathrm{u}^{1,2,3^{*}}$

\begin{abstract}
Background: Polyketides, such as spinosad, are mainly synthesized in the stationary phase of the fermentation. The synthesis of these compounds requires many primary metabolites, such as acetyl-CoA, propinyl-CoA, NADPH, and succinyl-CoA. Their synthesis is also significantly influenced by NADH/NAD ${ }^{+}$. Rex is the sensor of NADH/NAD ${ }^{+}$redox state, whose structure is under the control of $\mathrm{NADH} / \mathrm{NAD}^{+}$ratio. The structure of rex controls the expression of many NADH dehydrogenases genes and cytochrome bd genes. Intracellular redox state can be influenced by adding extracellular electron acceptor $\mathrm{H}_{2} \mathrm{O}_{2}$. The effect of extracellular oxidoreduction potential on spinosad production has not been studied. Although extracellular oxidoreduction potential is an important environment effect in polyketides production, it has always been overlooked. Thus, it is important to study the effect of extracellular oxidoreduction potential on Saccharopolyspora spinosa growth and spinosad production.

Results: During stationary phase, S. spinosa was cultured under oxidative $\left(\mathrm{H}_{2} \mathrm{O}_{2}\right)$ and reductive (dithiothreitol) conditions. The results show that the yield of spinosad and pseudoaglycone increased 3.11 fold under oxidative condition. As $\mathrm{H}_{2} \mathrm{O}_{2}$ can be served as extracellular electron acceptor, the ratios of $\mathrm{NADH} / \mathrm{NAD}^{+}$were measured. We found that the ratio of $\mathrm{NADH} / \mathrm{NAD}^{+}$under oxidative condition was much lower than that in the control group. The expression of cyt $A$ and $c y t B$ in the rex mutant indicated that the expression of these two genes was controlled by rex, and it was not activated under oxidative condition. Enzyme activities of PFK, ICDH, and G6PDH and metabolites results indicated that more metabolic flux flow through spinosad synthesis.

Conclusion: The regulation function of rex was inhibited by adding extracellular electron acceptor- $\mathrm{H}_{2} \mathrm{O}_{2}$ in the stationary phase. Under this condition, many NADH dehydrogenases which were used to balance NADH/NAD ${ }^{+}$ by converting useful metabolites to useless metabolites and unefficient terminal oxidases (cytochrome bd) were not expressed. So lots of metabolites were not waste to balance. As a result, un-wasted metabolites related to spinosad and PSA synthesis resulted in a high production of spinosad and PSA under oxidative condition.
\end{abstract}

Keywords: Saccharopolyspora spinosa, Oxidative condition, $\mathrm{H}_{2} \mathrm{O}_{2}$, Rex, Metabolites

\footnotetext{
* Correspondence: wenyulu@tju.edu.cn

'Department of Biological Engineering, School of Chemical Engineering and

Technology, Tianjin University, Tianjin 300072, PR China

${ }^{2}$ Key Laboratory of system bioengineering (Tianjin University), Ministry of

Education, Tianjin 300072, PR China

Full list of author information is available at the end of the article
} 


\section{Background}

Spinosyns containing a 21-carbon tetracyclic lactone are produced by Saccharopolyspora spinosa [1]. Besides to the tetracyclic lactone core, spinosyns also contain two deoxysugars, tri-O-methylated rhamnose and forosamine. Pseudoaglycones (PSAs) that lack forosamine are direct intermediates of spinosyns. So far, studies have demonstrated that $S$. spinosa can synthesize more than 25 spinosyns that vary in structures and functions [2]. Among these spinosyns, spinosyn $\mathrm{A}$ and spinosyn $\mathrm{D}$, the mixture of which was called spinosad, are the most two abundant and effective spinosyns [2]. Spinosad has shown broadspectrum insecticidal activity and a high level of selectivity and effectivity. More importantly, spinosad has no effect on nontarget insects and mammals [3,4]. Because of these advantages, spinosad-based insect control pesticide was awarded the Presidential Green Chemistry Challenge Award in 1999 [5].

In the last few years, metabolic engineering, classic random mutagenesis, and fermentation process optimization have been used to improve the yield of spinosad [6]. By over-expression rhamnose-synthesizing genes with their own promoter the yield of spinosad was significantly improved [1]. Pan et al. [7] made a three-fold improvement by over-expression rhamnose-synthesizing genes under the control of PermE* promoter. Xue et al. [8] made a five-fold improvement through rational metabolic engineering. For the random mutagenesis, Liang et al. [9] made a 2.86-fold improvement of spinosad though UV mutagenesis. Besides, spinosad production was significantly improved through fermentation media optimization using response surface methodology [10]. However, there is no study on the effect of extracellular oxidoreduction potential (ORP) on S. spinosa growth, spinosad production, metabolism changes and enzyme activities.

Spinosad is produced in the stationary phase of the fermentation. Oxygen, however, is not always sufficiently provided in this stage because of the limitation of rotate speeds. The insufficient oxygen in this stage would lead to a rapid increase in the $\mathrm{NADH} / \mathrm{NAD}^{+}$ratio. The increase of $\mathrm{NADH} / \mathrm{NAD}^{+}$ratio may change DNA binding ability of rex, which is a sensor of NADH/NAD ${ }^{+}$redox state [11]. High NADH/NAD ${ }^{+}$ratio leads rex to lose affinity for target DNA. As a result, inefficient electron transport system-cytochrome $b d$ oxidase $(c y t A B C D)$ and many NADH dehydrogenases would be expressed [12]. These NADH dehydrogenases indicate enzymes that contain 'Rossmann fold' domain, which is structurally homologous to redox-sensing domain, such as alcohol dehydrogenase and lactate dehydrogenase [12]. The expression of these genes can modulate unbalanced NADH/NAD ${ }^{+}$ ratio at the expense of changing intracellular metabolites to useless byproducts and using inefficient energy producing system (cytochrome $b d$ oxidase). The intracellular ORP, which is determined mainly by the ratio of $\mathrm{NADH} / \mathrm{NAD}^{+}$, can be influenced by changing extracellular ORP. Extracellular ORP can be changed by adding oxidative or reductive substances, such as dithiothreitol (DTT), potassium ferricyanide, dissolved oxygen (DO), and $\mathrm{H}_{2} \mathrm{O}_{2}$ [13,14]. Among these substances, DO and $\mathrm{H}_{2} \mathrm{O}_{2}$ are electron acceptors. Whether and how extracellular ORP change the metabolism of $S$. spinosa would be important, because such information can give us a global metabolic view about the response of $S$. spinosa to the change of extracellular ORP. Besides, many useful clues about how to improve spinosad production can also be obtained.

In this paper, we describe the effect of oxidative condition, created by adding $\mathrm{H}_{2} \mathrm{O}_{2}$ in the stationary phage, on $S$. spinosa growth, spinosad and PSA production, and glucose consumption. Besides, the effect of oxidative condition on $\mathrm{NADH} / \mathrm{NAD}^{+}$ratio, gene expression of $c y t A B$, activities of key redox-dependent enzymes (PFK, $\mathrm{ICDH}$ and G6PDH) in glycolysis, TCA cycle and pentose phosphate pathway (PPP), and intracellular metabolites change were also studied.

\section{Results}

Spinosad and PSA production and S. spinosa growth under different extracellular oxidation-reduction potentials

Batch cell growth, spinosad production, and fermentation parameters were analyzed for the whole fermentation process under different extracellular oxidoreduction potential. Oxidative condition was created by adding $5 \mathrm{mmol} / \mathrm{L} \mathrm{H}_{2} \mathrm{O}_{2}$ every $12 \mathrm{~h}$ from the initial of stationary stage of the fermentation, $72 \mathrm{~h}$. Reducing condition was created by adding $3 \mathrm{~g} / \mathrm{L}$ DTT at the initial of stationary stage of the fermentation, $72 \mathrm{~h}$. Because high $\mathrm{H}_{2} \mathrm{O}_{2}$ concentration can jeopardize $S$. spinosa growth, $5 \mathrm{mmol} / \mathrm{L}$ $\mathrm{H}_{2} \mathrm{O}_{2}$ was added every 12 h. $5 \mathrm{mmol} / \mathrm{L}_{2} \mathrm{O}_{2}$ did not affect S. spinosa growth and was consumed totally in $12 \mathrm{~h}$ (data not shown). Cell growth, spinosad production, and glucose consumption under different conditions were shown in Figure 1. Cell growth between the control group and reducing group shown no difference (Figure 1A). While dry cell weight (DCW) under oxidative condition was increased slightly, less than $4 \%$. In contrast, glucose consumption between control and oxidative condition did not have difference. Glucose consumption rate under reducing condition was increased (Figure 1B). The total yield of spinosad and PSA under oxidative condition reached $308 \mathrm{mg} / \mathrm{L}$, which was 3.11 fold of that in control group (Figure 1C). In contrast, the yield of spinosad and PSA under reducing condition was decreased significantly. Figure $1 \mathrm{C}$ shows that oxidative condition in stationary stage of fermentation was favorable for the production of spinosad. 

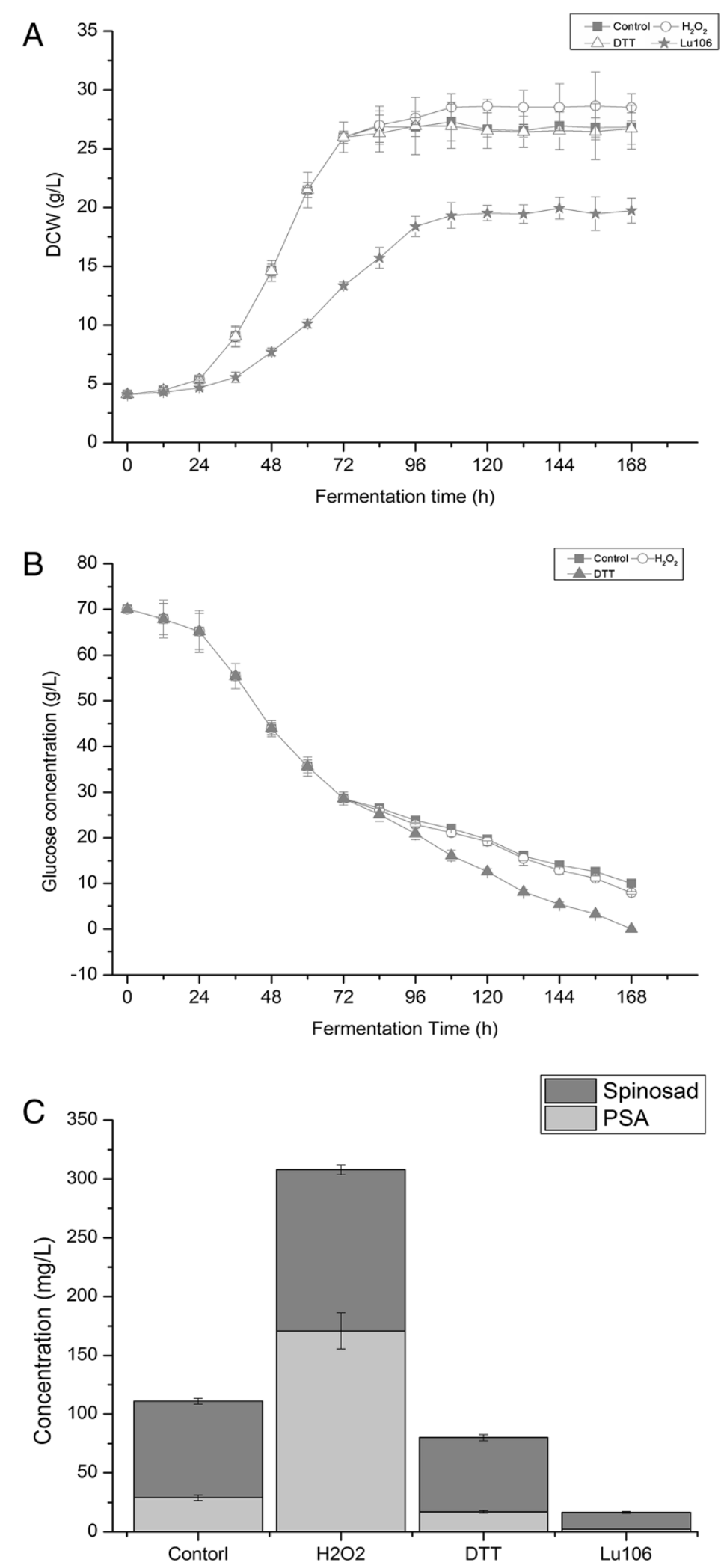

Figure 1 (See legend on next page.) 
(See figure on previous page.)

Figure 1 Effect of different fermentation conditions on cell growth, glucose consumption, spinosad and PSA production of wild-type S. spinosa, and cell growth spinosad and PAS production of rex-mutant Lu106. (A) Fermentation curve of rex-mutant Lu106 under control condition (star) and fermentation curve of wild-type under control condition (square), oxidative condition- $\mathrm{H}_{2} \mathrm{O}_{2}$ (circle), and reductive condition- DTT (triangle); (B) Glucose consumption of wild-type under control condition (square), oxidative condition- $\mathrm{H}_{2} \mathrm{O}_{2}$ (circle), and reductive condition- DTT (triangle); (C) Spinosad and PSA production of rex-mutant Lu106 under control condition and spinosad and PSA production of wild-type under control condition (control), oxidative condition- $\mathrm{H}_{2} \mathrm{O}_{2}$, and reductive condition- DTT.

\section{Intracellular NADH/NAD ${ }^{+}$levels}

As $\mathrm{H}_{2} \mathrm{O}_{2}$ is an electron acceptor, the differences of the ratios of $\mathrm{NADH} / \mathrm{NAD}^{+}$between the control and oxidative condition were analyzed. As shown in Figure 2 the ratios of $\mathrm{NADH} / \mathrm{NAD}^{+}$from $24 \mathrm{~h}$ to $48 \mathrm{~h}$ were maintained about 0.31 . Then the ratios of $\mathrm{NADH} / \mathrm{NAD}^{+}$were increased and reached 0.52 at $72 \mathrm{~h}$. After $72 \mathrm{~h}$, the ratios of $\mathrm{NADH} / \mathrm{NAD}^{+}$in the control group were maintained higher than 0.52 , while the ratios of $\mathrm{NADH} / \mathrm{NAD}^{+}$under oxidative condition were decreased to and maintained at 0.28 to 0.32 . It means that the ratios of $\mathrm{NADH} / \mathrm{NAD}^{+}$in the stationary phase were higher than that in the exponential phase in the control group. However, the ratios of $\mathrm{NADH} / \mathrm{NAD}^{+}$in the stationary phase were almost the same as that in the exponential phase under oxidative condition (Figure 2). These results indicate that the redox status in S. spinosa was significantly influenced.

\section{Rex and cytochrome bd oxidase genes determination and} expression assays

Studies have demonstrated that the rex regulator responds to intracellular NADH/NAD ${ }^{+}$levels and controls the expression of genes involved in lots of metabolisms in Actinomycetales [15]. The complete genome of S. spinosa ATCC 49460, accession number NZ_GL877878 in the NCBI nucleotide database (http://www.ncbi.nlm.nih. gov/nuccore/NZ_GL877878.1), was blasted with rex in Saccharopolyspora erythraea, Streptomyces coelicolor, and Streptomyces avermitilis by using the BLASTP algorithm with significant sequence similarity $\left(\mathrm{E}\right.$ value $\left.<10^{-40}\right)$. The rex gene in the $S$. spinosa genome sequencing was identified (Additional file 1: Figure S1) [15]. By blasting genes located in the downstream of rex with the genome of Saccharopolyspora erythraea, Streptomyces coelicolor, and Streptomyces avermitilis, we found that genes located in the downstream of rex were cytochrome $b d$ oxidase synthesis gene, $c y t A B$.

The expression of $c y t A$ and $c y t B$ were monitored using RT-qPCR to (I) prove that higher $\mathrm{NADH} / \mathrm{NAD}^{+}$levels can activate rex, the activation of rex controls the expression of $c y t A$ and $c y t B$, (II) use the expression of $c y t A$ and $c y t B$ to indicate whether rex was activated. The expression of $c y t A$ and $c t y B$ in $72 \mathrm{~h}$ was assigned as the reference. As shown in Figure 3, cyt $A$ and $c y t B$ were not expressed at the lag phase and exponential stage. $c y t A$ and $c y t B$ began to express at the initial of stationary

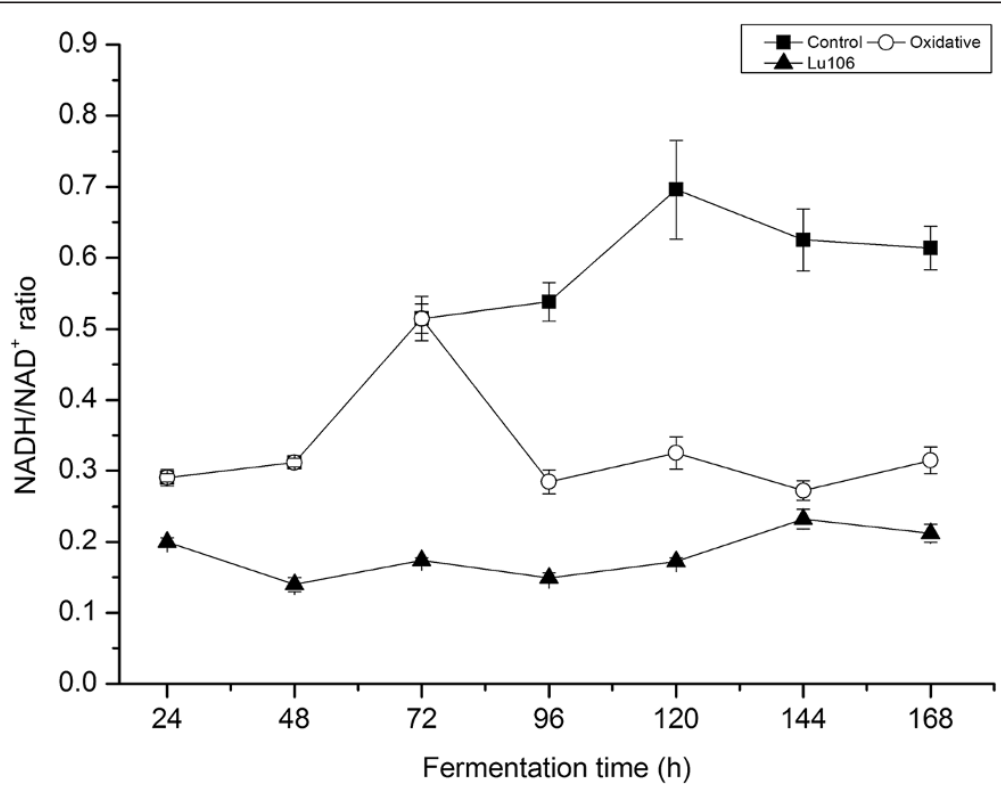

Figure $2 \mathrm{NADH} / \mathrm{NAD}^{+}$ratio of rex-mutant Lu106 under control condition (triangle) and wild-type under control condition (square) and oxidative condition (circle). 

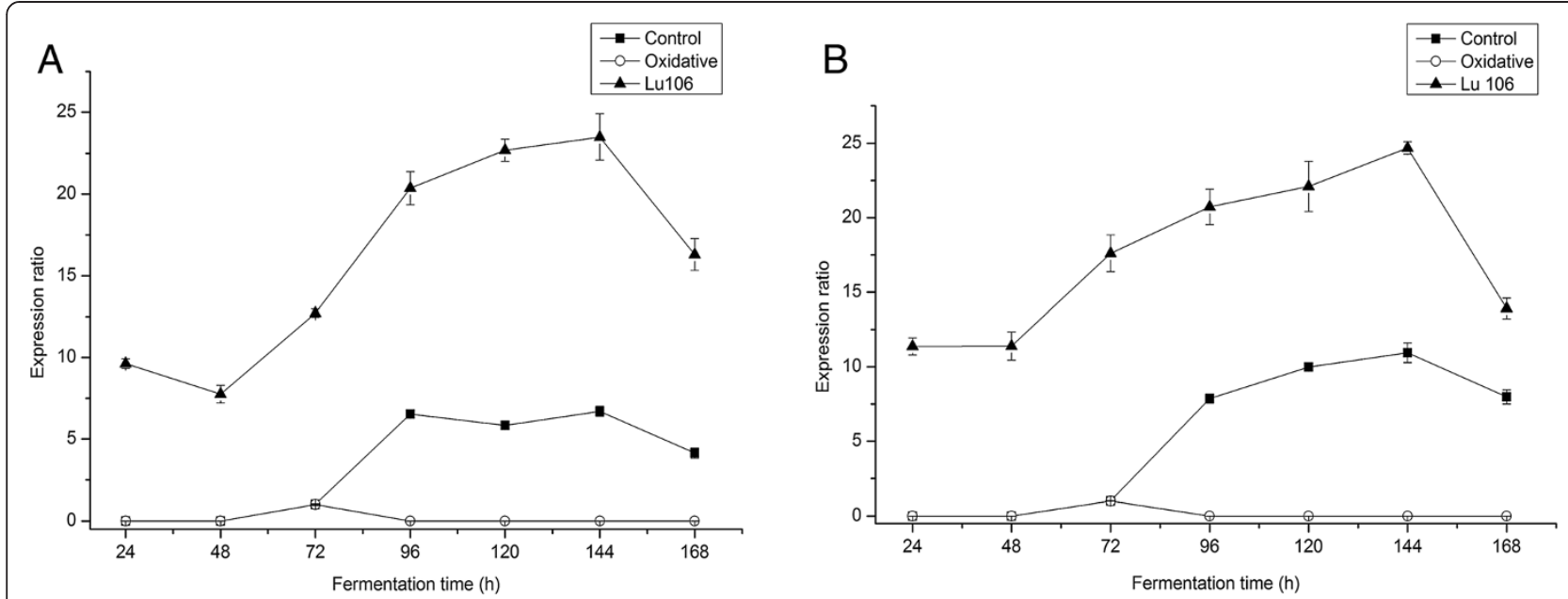

Figure 3 Gene expression ratios of $\boldsymbol{c y t} \mathbf{A}$ and $\boldsymbol{c y t} \mathbf{B}$. Relative gene expression ratios of $c y t A(\mathbf{A})$ or $c y t B(\mathbf{B})$ of rex-mutant Lu106 under control condition (triangle) and wild-type under control condition (square) and oxidative condition (circle).

phase, $72 \mathrm{~h}$. During the whole stationary phase, cyt $A$ and $c y t B$ were expressed continuously in the control group. In contrast, the expression of $c y t A$ and $c y t B$ in the stationary phase was ceased after adding $\mathrm{H}_{2} \mathrm{O}_{2}$ at $72 \mathrm{~h}$ (Figure 3). The expression profiles of $c t y A$ and $c t y B$ both in the control group and the oxidative condition were consistent with $\mathrm{NADH} / \mathrm{NAD}^{+}$levels (Figure 2). When the ratio of NADH/ $\mathrm{NAD}^{+}$was higher than 0.52 in S. spinosa, rex had a conformation change and the DNA binding abilities of rex were inhibited. As a result, rex-regulated genes, such as $c y t A$ and $c y t B$, were expressed (Figure 3).

\section{Rex deletion}

To further study the relationship between the expression of $c y t A B$ and rex and have a better understanding about the effect of oxidative condition on $S$. spinosa growth and spinosad and PSA production, the rex mutant (S. spinosa Lu106) was constructed. Cell growth, spinosad and PSA production, $\mathrm{NADH} / \mathrm{NAD}^{+}$levels, and gene expressions of cytA and cytB of S. spinosa Lu106 were studied. As shown in Figure 1A, the growth of S. spinosa Lu106 exhibited a growth defect relative to that of the wild type. Besides, the entry into stationary phase of rex mutant was delayed relative to that of the wild type (Figure 1A). The yield of spionsad and PSA in rex mutant was severely decreased (Figure $1 \mathrm{C}$ ). The NADH/NAD ${ }^{+}$levels in rex mutant were most stable during the whole fermentation process and maintained at a lower level (Figure 2). As shown in Figure 3, $c y t A$ and $c y t B$ were expressed from the beginning the fermentation. The expression of these two genes was very stable during the lag phage and exponential phase (Figure 3). At the stationary phase, the expression ratios increased (Figure 3 ). These results indicated that the expression of $c y t A B$ was regulated not only by rex but also some other genes. These results pointed out that cytochrome bd oxidase (cytAB) and many NADH dehydrogenases were continuously expressed in the rex mutant, which will consume many metabolites and NADH. As a result, cell growth and other compound synthesis, such as spinosad and PSA, were repressed.

\section{Enzyme activities analysis}

Further insights into the physiological consequences caused by oxidative condition were obtained by determining the activities of key redox-dependent enzymes (PFK, ICDH and G6PDH) in glycolysis, TCA cycle, and PPP. Although the activities of PFK in the stationary phage decreased with the time in both the control group and the oxidative condition, PFK activities decreased more sharply under oxidative condition than that in the control group in the whole stationary phase (Figure 4A). As shown in Figure 4B, the activities of ICDH in the control group $\left(0.22 \mathrm{uM} \mathrm{mg}^{-1} \mathrm{~min}^{-1}\right)$ was different from $(\mathrm{P}<0.05)$ that in the oxidative group $\left(0.2 \mathrm{uM} \mathrm{mg}^{-1} \mathrm{~min}^{-1}\right)$ during the whole stationary phage. As shown in Figure 4C, G6PDH activities show opposite results to PFK and ICDH. The activities of G6PDH under oxidative condition were much higher than that in the control group (Figure 4C).

\section{Intracellular metabolites analysis}

As we have shown, the oxidative condition can influence $S$. spinosa growth, spinosad and PSA production, rex DNA binding ability which determines the expression of many NADH dehydrogenases and cytochrome $b d$ oxidases, and the key enzyme activities involved in glycolysis, TCA cycle and PPP. To obtain a detailed relationship between central carbon metabolism changes and spinosad synthesis, intracellular metabolites were analyzed by GCMS and HPLC both in the control group and oxidative 


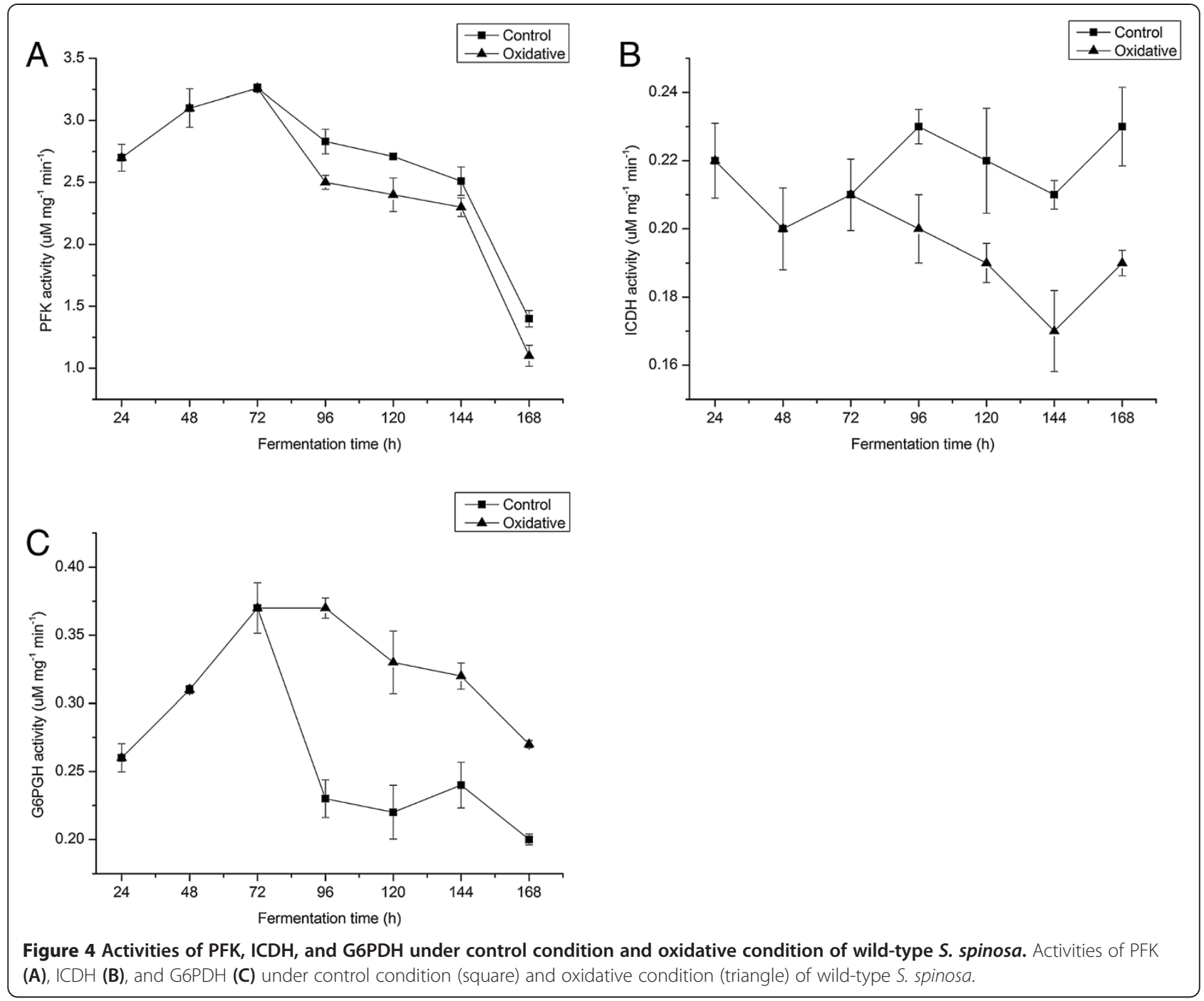

group (Additional file 2: Table S1). Metabolites involved in the central carbon metabolism and spinosad synthesis were determined (Table 1). As shown in Table 1, the concentrations of key metabolite 6-phophogluconate, involved in PPP were almost the same between the oxidative group and the control group during the whole stationary phase. In contrast, concentrations of key metabolites in glycolysis, citrate cycle, and spinosad synthesis were all higher under oxidative condition than that in the control. So, higher production of PSA and spinosad would be resulted from the higher concentrations of these central carbon metabolites and spinosad synthesis related metabolites. A whole metabolic explanation was illustrated in Figure 5.

\section{Discussion}

It has been found that under oxidative conditions, more flux flow through the synthesis of spinosad and cell growth, less flux flow through the synthesis of PSA and spinosad under reductive conditions. These results indicated that extracellular ORP can influence the metabolic flux. This is consistent with Christophe's study which demonstrated that extracellular ORP can modify carbon and electron flow in E. coli [16]. In our study, DTT and $\mathrm{H}_{2} \mathrm{O}_{2}$ were used to modify the extracellular ORP. Because of the toxicity of high concentration of $\mathrm{H}_{2} \mathrm{O}_{2}$, we chose to add $\mathrm{H}_{2} \mathrm{O}_{2}$ every $12 \mathrm{~h}$ to create the oxidative condition. Because the addition of $\mathrm{H}_{2} \mathrm{O}_{2}$ can improve the yield of PSA and spinosad, further study about the response of $S$. spinosa was performed.

During the stationary phase, $\mathrm{NADH} / \mathrm{NAD}^{+}$ratios in the control group were higher than that in the oxidative group (Figure 2). In the control group, $\mathrm{NADH} \mathrm{NAD}^{+}$ratios in the stationary phase were higher than that in the lag phase and exponential stage (Figure 2). However, $\mathrm{NADH} / \mathrm{NAD}^{+}$ratios in the stationary phase were more stable and almost the same as that in the lag phase and exponential stage under the oxidative condition. Studies 
Table 1 the concentrations of key metabolites involved in glycolysis, citrate cycle, pentose phosphate pathway and spinosad synthesis under the control and oxidative condition

\begin{tabular}{|c|c|c|c|c|c|c|c|c|c|c|}
\hline \multirow[t]{2}{*}{ Metabolites } & \multicolumn{2}{|c|}{$72 \mathrm{~h}$} & \multicolumn{2}{|c|}{$96 \mathrm{~h}$} & \multicolumn{2}{|c|}{$120 \mathrm{~h}$} & \multicolumn{2}{|c|}{$144 \mathrm{~h}$} & \multicolumn{2}{|c|}{$168 \mathrm{~h}$} \\
\hline & Control $^{\mathrm{a}}$ & Oxidative & Control & Oxidative & Control & Oxidative & Control & Oxidative & Control & $\overline{\text { Oxidative }}$ \\
\hline \multicolumn{11}{|l|}{ Glycolysis } \\
\hline Fructose-6-P & 1 & 1 & 1.13 & 1.62 & 0.94 & 1.35 & 1.26 & 0.75 & 0.67 & 0.93 \\
\hline glyceraldehyde 3-phosphate & 1 & 1 & 0.97 & 1.54 & 1.00 & 2.09 & 0.94 & 1.21 & 0.96 & 0.53 \\
\hline Pyruvate & 1 & 1 & 1.26 & 1.56 & 1.79 & 1.24 & 0.81 & 1.50 & 1.16 & 1.38 \\
\hline Acetyl-CoA & 1 & 1 & 1.31 & 1.79 & 1.06 & 2.53 & 1.22 & 0.97 & 0.52 & 0.89 \\
\hline L-Lactate & 1 & 1 & 2.32 & 0.35 & 1.39 & ND & 1.16 & 0.17 & 1.63 & ND \\
\hline \multicolumn{11}{|l|}{ Pentose phosphate pathway } \\
\hline Glucose-6-P & 1 & 1 & 1.74 & 6.20 & 2.16 & 7.22 & 1.92 & 7.16 & 1.31 & 4.97 \\
\hline 6-phosphogluconate & 1 & 1 & 0.73 & 0.81 & 0.44 & 0.53 & 0.25 & 0.21 & ND & 0.14 \\
\hline \multicolumn{11}{|l|}{ Citrate cycle } \\
\hline Citrate & 1 & 1 & 1.29 & 2.89 & 1.12 & 1.96 & 0.93 & 1.89 & 0.77 & 1.37 \\
\hline Oxaloacetate & 1 & 1 & 0.59 & 1.28 & 0.41 & 1.05 & 0.37 & 0.92 & 0.46 & 0.79 \\
\hline Succinyl-CoA & 1 & 1 & 1.62 & 3.42 & 1.73 & 4.11 & 1.07 & 3.21 & 0.93 & 3.07 \\
\hline \multicolumn{11}{|l|}{ Spinosad synthesis related } \\
\hline Threonine & 1 & 1 & 1.16 & 1.39 & 0.50 & 0.85 & 0.26 & 0.68 & ND & 0.42 \\
\hline Valine & 1 & 1 & 1.14 & 2.69 & 1.69 & 3.99 & 1.92 & 3.51 & 0.25 & 0.73 \\
\hline Isoleucine & 1 & 1 & 0.51 & 1.17 & 0.27 & 0.86 & 0.20 & 0.57 & 0.26 & 0.45 \\
\hline Propionyl-CoA & 1 & 1 & 1.47 & 2.73 & 1.94 & 3.16 & 1.86 & 3.37 & 1.66 & 2.79 \\
\hline Malonyl-CoA & 1 & 1 & 1.24 & 1.99 & 1.17 & 1.48 & 0.97 & 1.72 & 1.10 & 1.91 \\
\hline Methylmalonyl-CoA & 1 & 1 & 1.05 & 1.50 & 1.03 & 1.44 & 1.21 & 1.90 & 0.88 & 1.16 \\
\hline
\end{tabular}

${ }^{a}$ :The concentration at $72 \mathrm{~h}$ was the set as 1; ND: Under the lower limit of detection.

have demonstrated that $\mathrm{H}_{2} \mathrm{O}_{2}$ is electron acceptor [17]. During the fermentation process, $\mathrm{H}_{2} \mathrm{O}_{2}$ accepted electrons from NADH directly or was degraded to $\mathrm{H}_{2} \mathrm{O}$ and $\mathrm{O}_{2}$. As a result, part of $\mathrm{NADH}$ was oxidized by $\mathrm{H}_{2} \mathrm{O}_{2}$ that resulted in the lower $\mathrm{NADH} / \mathrm{NAD}^{+}$ratios under oxidative condition. During the fermentation of Actinomycetes, high stirring speed damages the mycelium [18]. And the mycelium morphology of Actinomycetes plays an important role in polyketides production [19]. Our study found that electron acceptors can be provided without increasing stirring speed, which would damage the mycelium morphology of Actinomycetes.

Rex is a sensor of NADH/NAD ${ }^{+}$in many Grampositive bacteria, including S. coelicolor [11], S. erythraea [15], and B. subtilits [20]. By sensing cellular NADH/ $\mathrm{NAD}^{+}$, rex regulates the transcription of many genes involved in central carbon metabolism, NADH reoxidation, such as cytochrome $b d$ oxidase (cytAB) and NADH dehydrogenases to maintain cellular redox balance [11]. In the rex mutant $c y t A$ and $c y t B$ were expressed in the whole fermentation process, which indicated that the expression of $c y t A$ and $c y t B$ was influenced by rex in $S$. spinosa. We also found that the expression of $c y t A$ and $c y t B$ was also influenced by other regulation factors
(Figure 3). Under oxidative condition, $c y t A$ and $c y t B$ were not expressed. This indicated that the DNA binding ability of rex was abolished. This result is consistent with $\mathrm{NADH} / \mathrm{NAD}^{+}$ratios in oxidative condition (Figure 2). It also indicates that many other NADH dehydrogenases, such as alcohol dehydrogenase and lactate dehydrogenase, were not expressed.

The activities of three key enzymes involved in EMP, TCA, and PPP were analyzed. Although studies have demonstrated that in vitro measured enzymatic activity do not obligatorily correlate with in vivo metabolic fluxes [21], enzyme activity can provide some information about metabolic changes. The lower activities of PFK and ICDH under oxidative condition than that in the control group indicated that PFK and ICDH were allosterically inhibited by higher metabolites concentrations in EMP and TCA under oxidative condition [22]. Metabolites measurement certified the enzyme activity result. Although metabolites involved in PPP under oxidative condition were higher than that in the control group, G6PDH activity under oxidative condition was still higher than that in the control group. G6PDH activity results indicated that PPP pathway was significantly upregulated under oxidative condition. 


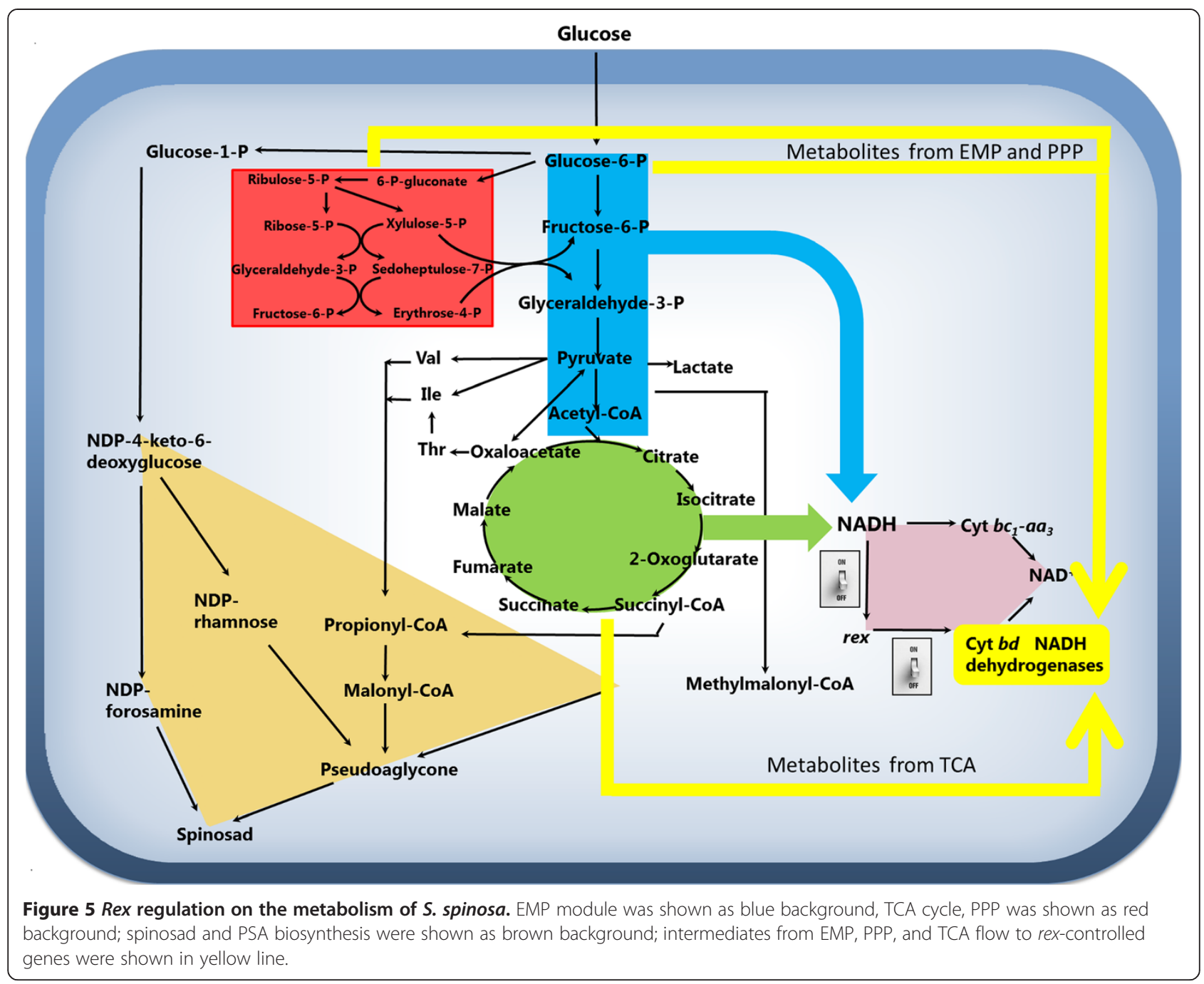

The synthesis of spinosad and PSA requires many primary metabolites, such as acetyl-CoA, propinyl-CoA, $\mathrm{NADPH}$, and succinyl-CoA, in the stationary phase of the fermentation [23,24]. As shown in Table 1, the concentrations of spinosad and PSA direct precursors, glucose-6-P, acetyl-CoA, propionyl-CoA, malonyl-CoA, and methylmalonyl-CoA in oxidative group were much higher than that in the control group. Besides, the concentrations of acetyl-CoA and propionyl-CoA related precursors, succinyl-CoA, threonine, valine, and isoleucine were also higher in oxidative group. Taken together we found that the concentrations of most of precursors related to spinosad and PSA synthesis was higher under oxidative condition than that in control condition (Table 1). The gene expression results indicated that the DNA binding ability of rex was abolished under oxidative condition. Because of the inhibition of rex regulation, many NADH dehydrogenases and inefficient terminal oxidases (cytochrome $b d$ ) were not expressed. So lots of metabolites were not waste to balance $\mathrm{NADH} / \mathrm{NAD}^{+}$metabolism under oxidative condition. The explanation of the whole process was illustrated in Figure 5.

\section{Conclusions}

The regulative function of rex was inhibited by adding extracellular electron acceptor- $\mathrm{H}_{2} \mathrm{O}_{2}$ in the stationary phase. Under this condition, many NADH dehydrogenases which were used to balance NADH/NAD ${ }^{+}$by converting useful metabolites to useless metabolites and inefficient terminal oxidases (cytochrome $b d$ ) were not expressed. So lots of metabolites were not wasted to balance. As a result, un-wasted metabolites related to spinosad and PSA synthesis resulted in a high prodution of spinosad and PSA under oxidative condition (Figure 5).

\section{Methods}

Strains, mutant construction and growth conditions

Plasmids and stains used in this study are listed in Table 2. Escherichia. coli DH5 $\alpha$ and Top10 were used for plasmid construction and amplification. E. coli S17-1 
Table 2 The strains and plasmids used in this study

\begin{tabular}{|c|c|c|}
\hline Strain or plasmids & Description & $\begin{array}{l}\text { Source or } \\
\text { reference }\end{array}$ \\
\hline \multicolumn{3}{|l|}{ Strains } \\
\hline E. coli DH5a & Host for general cloning & $\begin{array}{l}\text { TransGen } \\
\text { Biotech }\end{array}$ \\
\hline E. coli TOP10 & Host for general cloning & $\begin{array}{l}\text { TransGen } \\
\text { Biotech }\end{array}$ \\
\hline E. coli S17-1 & $\begin{array}{l}\text { Donor stain for conjugation } \\
\text { between } E \text {. coli and S. spinosa }\end{array}$ & {$[25]$} \\
\hline $\begin{array}{l}\text { S. spinosa ATCC } \\
49460\end{array}$ & Wild strain & [26] \\
\hline $\begin{array}{l}\text { S. spinosa } \\
\text { Lu106 }\end{array}$ & S. spinosa ATCC 4946 with pLu106 & This study \\
\hline \multicolumn{3}{|l|}{ Plasmids } \\
\hline POJ260 & $\begin{array}{l}\text { E. coli - Streptomcyes shuttle vector; } \\
\text { apr oriT rep }{ }^{P U C} \text { lacZ }\end{array}$ & {$[27]$} \\
\hline pLu106 & pOJ260 with truncated Rex & This study \\
\hline
\end{tabular}

was used as the door strain in biparental intergeneric conjugations. Saccharopolyspora spinosa ATCC 49460 was used as the parent strain.

Oligonucleotide primers used in this study are listed in Table 3. To construct rex mutant S. spinosa, first, part of rex $(604 \mathrm{bp})$ fragment was amplified from genomic DNA of S. spinosa using primer pairs of rex-F-HindIII, rex-RXbaI. Then the 604 bp fragment was digested by HindIII (Fermentas) and XbaI (Fermentas) and ligated to pOJ260 obtaining pLu106. pLu106 was introduced into S. spinosa ATCC 49460 by conjugation from E. coli S17-1 and homologous recombination into the chromosome as described previously [28]. The plasmid was inserted into the middle rex of S. spinosa ATCC 49460 to create S. spinosa ${ }^{\Delta}$ rex (Lu106). S. spinosa $\triangle$ rex was confirmed by PCR amplification with primers Con-F and Con-R.

Table 3 Sequences of oligonucleotide primers used in this study

\begin{tabular}{ll}
\hline Primers & Sequence $\mathbf{5}^{\prime} \boldsymbol{\rightarrow} \mathbf{3}^{\prime}$ \\
\hline rex-F-HindIII & CTAAGCTTTGTCCGCACTCGCCGAC \\
rex-R-Xbal & CTTCTAGAATCCACATCGGATCGATCGG \\
cydA-R- & TATCGCACCGGCAAGCAG \\
cydB-F & GAACTCCTGCACGATGCC \\
cydB-R- & GATCTGCCCACCTTCTGG \\
Con-F & CATGCCGACGCCGAAGTC \\
Con-R & CCGTGATTTGTAGCCCTGG \\
16S rRNA-F & GGCCTACTTCACCTATCCTGC \\
16S rRNA-R & CCTACGAGCTCTTACGCCC \\
rbL13-F & AGAAGCACCGGCTAACTACG \\
rbL13-R & GGCGTAGACCTTGAGCTTC \\
\hline
\end{tabular}

E. coli strains were grown at $37^{\circ} \mathrm{C}$ in Luria-Bertani medium. Apramycin was used as a selection agent at $100 \mathrm{ug} / \mathrm{ml}$ for $E$. coli and at $50 \mathrm{ug} / \mathrm{ml}$ for S. spinosa. S. spinosa were cultured as described [8]. First, S. spinosa was cultured for 3 days in seed medium $(\mathrm{g} / \mathrm{L})$ which was composed by Trypticase soy broth, 30; yeast extract, $3 ; \mathrm{MgSO}_{4} \cdot 7 \mathrm{H}_{2} \mathrm{O}, 2$; glucose, 10 ; and maltose, $4, \mathrm{pH} 7.2$. Then $3 \mathrm{~mL}$ of seed medium were injected into $30 \mathrm{~mL}$ fermentation medium (g/L) which was composed by glucose, 68; cottonseed flour, 22; peptone $\mathrm{C}, 25$; corn seed liquor, 14.5; methyl oleate, 40; and $\mathrm{CaCO}_{3}, 5, \mathrm{pH}$ 7.2. The fermentation medium was optimized by response surface methods [10].

\section{Determination of spinosad and S. spinosa growth}

Spinosad in fermentation broth was extracted and determined by HPLC as described [10]. Dry cell weight (DCW) was determined as described [29]. Glucose was measured by using the dinitrosalicylic acid (DNS) method [30]. The experiments were repeated three times.

\section{NADH and $\mathrm{NAD}^{+}$extraction and determination}

$\mathrm{NADH}$ and $\mathrm{NAD}^{+}$were extracted according to a previous described method with some modifications [31]. $5 \mathrm{~mL}$ cell cultures were collected, chilled on ice immediately, and centrifuged at $12000 \mathrm{~g}, 4^{\circ} \mathrm{C}$ for $10 \mathrm{~min}$. Then cell pellets were immediately ground to powder in a porcelain mortar, which was pre-cooled to $-80^{\circ} \mathrm{C}$, under liquid nitrogen for $5 \mathrm{~min}$. After that, $\mathrm{NADH}$ was extracted by the addition of $300 \mathrm{uL} 0.2 \mathrm{~mol} / \mathrm{L} \mathrm{NaOH}$. NAD ${ }^{+}$was extracted by the addition of $300 \mathrm{uL} 0.2 \mathrm{~mol} / \mathrm{L} \mathrm{HCl}$. Then the samples were heated at $50^{\circ} \mathrm{C}$ for $10 \mathrm{~min}$ and neutralized using $\mathrm{NaOH}$ or $\mathrm{HCl}$. After neutralization, the samples were centrifuged at $12000 \mathrm{~g}, 4^{\circ} \mathrm{C}$ for $10 \mathrm{~min}$. The supernatant was collected and stored at $-80^{\circ} \mathrm{C}$ until used. $\mathrm{NADH}$ and $\mathrm{NAD}^{+}$in the supernatant were determined using NAD/NADH quantitation kit (Comin), according to manufacturer's instructions. The kit is based on an enzymatic cycling assay method.

\section{Enzyme activity assays}

$20 \mathrm{~mL}$ cell cultures were collected, chilled on ice immediately, and centrifuged at $3000 \mathrm{~g}, 4^{\circ} \mathrm{C}$ for $10 \mathrm{~min}$. Cell pellets were suspended in $2 \mathrm{~mL}$ Tris- $\mathrm{HCl}$ buffer $(100 \mathrm{mM}$, $\mathrm{pH}$ 7.2) and disrupted by sonication on ice for $5 \mathrm{~min}$ (pulse intensity 40\%, pulse on for $10 \mathrm{~s}$ and off for $50 \mathrm{~s}$ ). After centrifugation $\left(12000 \mathrm{~g}, 4^{\circ} \mathrm{C}\right.$ for $\left.30 \mathrm{~min}\right)$, the supernatant was used for enzyme assay. 6-phosphofructokinase (PFK) activity was determined as described [31]. Isocitrate dehydrogenase (ICDH) activity was determined by measuring the production of NADH [32]. Glucose6-phophate dehydrogenase (G6PDH) activity was carried out by measuring the formation of NADPH as described previously [33]. 


\section{RNA extraction, cDNA synthesis, and real-time qPCR analysis}

RNA extraction, cDNA synthesis, and real-time qPCR analysis of $S$. spinosa were performed as described previously [34]. 16S rRNA and rbL13 were used to normalize the qPCR data. The primers used in qPCR are listed in Table 3.

\section{Intracellular metabolites using GC-MS}

$4 \mathrm{~mL}$ cell cultures were mixed with $6 \mathrm{~mL}$ cold methanol $\left(-40^{\circ} \mathrm{C}\right)$ to arrest metabolism instantaneously. Then, samples were centrifugated at $3000 \mathrm{~g}$ for $3 \mathrm{~min}$. Cell pellets were collected and immediately ground to powder in a porcelain mortar, which was pre-cooled to $-80^{\circ} \mathrm{C}$, under liquid nitrogen for $5 \mathrm{~min}$. Then $100 \mathrm{mg}$ cell powder was mixed thoroughly with $1 \mathrm{ml}-40^{\circ} \mathrm{C} 50 \%$ methanol (methanol/water, 1:1). The samples were centrifugated at $10000 \mathrm{~g}$ for $10 \mathrm{~min}$. The supernatants were collected. Then $10 \mathrm{uL}$ internal standard solution succinic $d_{4}$ acid (Sigma, $0.1 \mathrm{mg} / \mathrm{ml}$ ) was added into the $100 \mathrm{uL}$ extract supernatants before lyophilization. After lyophilization, the derivatization and measurement by GC-MS of these samples were carried out according to a previous method [35]. Four biological replicates were performed for each sample. The identification and quantification of GC-MS peaks were performed using Agilent software (G1701DA MSD ChemStation ver. D.00.00.38).

\section{Metabolites involved in Spinosad synthesis determination} Short chain coenzyme A (CoA) in S. spinosa was extracted as described [8]. Acetly-CoA, malonayl-CoA, methylmalonyl-CoA, succinyl-CoA, and propionyl-CoA were measured by HPLC as described [36]. Pseudoaglycones (PSA), the intermediates of spinosad, was determined by HPLC as described [37].

\section{Additional files}

Additional file 1: Figure S1. Multiple alignments of proteins from Rex family.

Additional file 2: Table S1. The intracellular metabolites involved in Carbohydrate metabolism, Energy metabolism, Lipid metabolism, Amino acid metabolism, Nucleotide metabolism and spinosad pathway were analyzed by GC-MS and HPLC both in the control group and oxidative condition.

\section{Competing interests}

The authors declare that they have no competing interest.

\section{Authors' contributions}

$X M Z$ and $W Y L$ designed the experiments. XMZ and CYX performed all the experiments and prepared all figures. FLZ and DSL performed mass spectrometry analysis. XMZ, CYX, CBZ, QGLCY and WYL co-drafted the manuscript. All authors read and approved the final manuscript.

\section{Acknowledgements}

The authors wish to acknowledge the financial supported by National Natural Science Foundation of China (No. 31270087 and 21076148), National Key Basic Research Program (No. 2012CB721105), Program for New Century
Excellent Talents in University (NCET-10-0616) and Natural Science Foundation of Tianjin (No. 10JCYBJC10300).

\section{Author details}

${ }^{1}$ Department of Biological Engineering, School of Chemical Engineering and Technology, Tianjin University, Tianjin 300072, PR China. ${ }^{2}$ Key Laboratory of system bioengineering (Tianjin University), Ministry of Education, Tianjin 300072, PR China. ${ }^{3}$ Collaborative Innovation Center of Chemical Science and Engineering (Tianjin), Tianjin 300072, PR China.

Received: 8 March 2014 Accepted: 26 June 2014

Published online: 27 August 2014

\section{References}

1. Madduri K, Waldron C, Matsushima P, Broughton MC, Crawford K, Merlo DJ, Baltz RH: Genes for the biosynthesis of spinosyns: applications for yield improvement in Saccharopolyspora spinosa. J Ind Microbiol Biotechnol 2001, 27:399-402.

2. Sparks TC, Crouse GD, Durst G: Natural products as insecticides: the biology, biochemistry and quantitative structure-activity relationships of spinosyns and spinosoids. Pest Manag Sci 2001, 57:896-905.

3. Williams $T$, Valle J, Viñuela E: Is the naturally derived insecticide

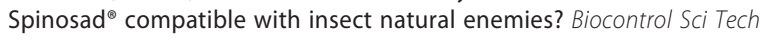
2003, 13:459-475.

4. Kirst HA: The spinosyn family of insecticides: realizing the potential of natural products research. J Antibiot 2010, 63:101-111.

5. Sarfraz M, Dosdall LM, Keddie BA: Spinosad: a promising tool for integrated pest management. Outlook Pest Manage 2005, 16:78-84.

6. Huang K, Xia L, Zhang Y, Ding X, Zahn JA: Recent advances in the biochemistry of spinosyns. Appl Microbiol Biotechnol 2009, 82:13-23.

7. Pan HX, Li JA, He NJ, Chen JY, Zhou YM, Shao L, Chen DJ: Improvement of spinosad production by overexpression of gtt and gdh controlled by promoter PermE* in Saccharopolyspora spinosa SIPI-A2090. Biotechnol Lett 2011, 33:733-739.

8. Xue C, Duan Y, Zhao F, Lu W: Stepwise increase of spinosad production in Saccharopolyspora spinosa by metabolic engineering. Biochem Eng J 2013, 72:90-95.

9. Liang Y, Lu W, Wen J: Improvement of Saccharopolyspora spinosa and the kinetic analysis for spinosad production. Appl Biochem Biotechnol 2009, 152:440-448.

10. Strobel RJ Jr, Nakatsukasa WM: Response surface methods for optimizing Saccharopolyspora spinosa, a novel macrolide producer. J Ind Microbiol 1993, 11:121-127.

11. Brekasis $D$, Paget MSB: A novel sensor of $\mathrm{NADH} / \mathrm{NAD}^{+}$redox poise in Streptomyces coelicolor A3 (2). EMBO J 2003, 22:4856-4865.

12. Green J, Paget MS: Bacterial redox sensors. Nat Rev Microbiol 2004, 2:954-966.

13. González-Siso MI, García-Leiro A, Tarrío N, Cerdán ME: Sugar metabolism, redox balance and oxidative stress response in the respiratory yeast Kluyveromyces lactis. Microb Cell Factories 2009, 8:46.

14. Liu CG, Xue C, Lin YH, Bai FW: Redox potential control and applications in microaerobic and anaerobic fermentations. Biotechnol Adv 2013, 31:257-265.

15. Ravcheev DA, Li X, Latif H, Zengler K, Leyn SA, Korostelev YD, Rodionov DA: Transcriptional regulation of central carbon and energy metabolism in bacteria by redox-responsive repressor Rex. J Bacterio/ 2012, 194:1145-1157.

16. Riondet $C$, Cachon $R$, Waché $Y$, Alcaraz G, Diviès C: Extracellular oxidoreduction potential modifies carbon and electron flow in Escherichia coli. J Bacteriol 2000, 182:620-626.

17. Kelly DJ: Metabolism, electron transport and bioenergetics of Campylobacter jejuni: implications for understanding life in the gut and survival in the environment. In Campylobacter, Molecular and Cellular Biology. Edited by Ketley JM, Konkel ME. Wymondham, UK: Horizon Bioscience; 2005:275-292.

18. Amanullah A, Blair R, Nienow AW, Thomas CR: Effects of agitation intensity on mycelial morphology and protein production in chemostat cultures of recombinant Aspergillus oryzae. Biotechnol Bioeng 1999, 62:434-446.

19. Carata E, Peano C, Tredici SM, Ferrari F, Talà A, Corti G, Alifano P: Phenotypes and gene expression profiles of Saccharopolyspora erythraea rifampicin-resistant (rif) mutants affected in erythromycin production. Microb Cell Fact 2009, 8:18. 
20. Wang E, Bauer MC, Rogstam A, Linse S, Logan DT, Von Wachenfeldt C: Structure and functional properties of the Bacillus subtilis transcriptional repressor Rex. Mol Microbiol 2008, 69:466-478.

21. Borodina I, Siebring J, Zhang J, Smith CP, Van Keulen G, Dijkhuizen L, Nielsen J: Antibiotic overproduction in Streptomyces coelicolor A3 (2) mediated by phosphofructokinase deletion. J Biol Chem 2008, 283:25186-25199.

22. Peng L, Shimizu K: Global metabolic regulation analysis for Escherichia coli $\mathrm{K} 12$ based on protein expression by 2-dimensional electrophoresis and enzyme activity measurement. Appl Microbiol Biotechnol 2003, 61:163-178.

23. Gramajo HC, Takano E, Bibb MJ: Stationary phase production of the antibiotic actinorhodin in Streptomyces coelicolor A3 (2) is transcriptionally regulated. Mol Microbiol 1993, 7:837-845.

24. Staunton J, Weissman KJ: Polyketide biosynthesis: a millennium review. Nat Prod Rep 2001, 18:380-416.

25. Simon R, Priefer U, Pühler A: A broad host range mobilization system for in vivo genetic engineering: transposon mutagenesis in gram negative bacteria. Nat Biotechnol 1983, 1:784-791.

26. Mertz FP, Yao RC: Saccharopolyspora spinosa sp. nov. isolated from soil collected in a sugar mill rum still. Int I Syst Bacteriol 1990, 40:34-39.

27. Bierman $M$, Logan $R$, O'brien $K$, Seno ET, Nagaraja Rao R, Schoner BE: Plasmid cloning vectors for the conjugal transfer of DNA from Escherichia coli to Streptomyces spp. Gene 1992, 116:43-49.

28. Matsushima P, Broughton MC, Turner JR, Baltz RH: Conjugal transfer of cosmid DNA from Escherichia coli to Saccharopolyspora spinosa: effects of chromosomal insertions on macrolide A83543 production. Gene 1994 146:39-45.

29. Puertas JM, Betton JM: Engineering an efficient secretion of leech carboxypeptidase inhibitor in Escherichia coli. Microb Cell Factories 2009, 8:57.

30. Miller $\mathrm{GL}$ : Use of dinitrosalicylic acid reagent for determination of reducing sugar. Anal Chem 1959, 31:426-428.

31. Berríos-Rivera SJ, Bennett GN, San KY: The effect of increasing NADH availability on the redistribution of metabolic fluxes in Escherichia coli chemostat cultures. Metab Eng 2002, 4:230-237.

32. Lin AP, McAlister-Henn L: Isocitrate binding at two functionally distinct sites in yeast $\mathrm{NAD}^{+}$-specific isocitrate dehydrogenase. J Biol Chem 2002, 277:22475-22483.

33. Ryu YG, Butler MJ, Chater KF, Lee KJ: Engineering of primary carbohydrate metabolism for increased production of actinorhodin in Streptomyces coelicolor. Appl Environ Microbiol 2006, 72:7132-7139.

34. Xue C, Zhang X, Yu Z, Zhao F, Wang M, Lu W: Up-regulated spinosad pathway coupling with the increased concentration of acetyl-CoA and malonyl-CoA contributed to the increase of spinosad in the presence of exogenous fatty acid. Biochem Eng J 2013, 81:47-53.

35. Ding MZ, Cheng JS, Xiao WH, Qiao B, Yuan YJ: Comparative metabolomic analysis on industrial continuous and batch ethanol fermentation processes by GC-TOF-MS. Metabolomics 2009, 5:229-238

36. Demoz A, Garras A, Asiedu DK, Netteland B, Berge RK: Rapid method for the separation and detection of tissue short-chain coenzyme $A$ esters by reversed-phase high-performance liquid chromatography. J Chromatogr B Biomed Sci Appl 1995, 667:148-152.

37. Creemer LC, Kirst HA, Paschal JW: Conversion of spinosyn A and spinosyn $D$ to their respective 9 -and 17 -pseudoaglycones and their aglycones. J Antibiot 1998, 51:795.

doi:10.1186/s12934-014-0098-z

Cite this article as: Zhang et al: Suitable extracellular oxidoreduction potential inhibit rex regulation and effect central carbon and energy metabolism in Saccharopolyspora spinosa. Microbial Cell Factories

\section{Submit your next manuscript to BioMed Central and take full advantage of:}

- Convenient online submission

- Thorough peer review

- No space constraints or color figure charges

- Immediate publication on acceptance

- Inclusion in PubMed, CAS, Scopus and Google Scholar

- Research which is freely available for redistribution 